\title{
Refuges for Movable Cultural Property in Wartime: Lessons for Contemporary Practice from Second World War Italy.
}

\section{Nigel Pollard, Swansea University}

\begin{abstract}
Experiences of the Second World War were recent to those who drafted the 1954 Hague Convention for the Protection of Cultural Property in the Event of Armed Conflict, and many of its provisions reflect those lessons (Boylan 1993; O’Keefe 2006; O’Keefe and Prott 2011, 16-57; O’Keefe et al. 2016). One under-used area of provision in Hague 1954 that reflects such experience relates to wartime shelters ('refuges') for movable cultural property including works of art, museum collections, books and archives..$^{1}$ This paper examines damage and risk to movable cultural property sheltered in refuges in Italy during the Second World War to demonstrate that their secrecy exposed them to damage by (i) careless military occupation, (ii) deliberate combatant damage, (iii) accidental and collateral damage, and (iv) looting. Hague 1954 provides for marked refuges for movable cultural property under both special and general protection, and these historical case studies also highlight some of the potential advantages (and problems) of internationally-recognised refuges in advertised locations, and of Hague 1954’s ‘special protection’ regime more generally.
\end{abstract}

\section{Introduction}

This paper explores aspects of the Second World War experience underpinning the little-used provisions for refuges in the 1954 Hague Convention for the Protection of Cultural Property in the Event of Armed Conflict, and examines their advantages and disadvantages relative to other approaches to the protection of movable cultural property in conflict. The first section 
considers legal aspects of that Hague provision and the characteristics of 'Hague-type' refuges, along with some of the factors that have made states reluctant to adopt them. The second section presents historical case studies from the Second World War (which itself influenced the drafting of Hague 1954) for comparison with the Hague provisions.

\section{Refuges for Movable Cultural Property in the 1954 Hague Convention}

Hague 1954, Article 8 states: 'There may be placed under special protection a limited number of refuges intended to shelter movable cultural property in the event of armed conflict.' These refuges must be located at ‘an adequate distance’ from any large industrial centre or from any important military objective or 'be so constructed that, in all probability, [they] will not be damaged by bombs.' 'Special protection' of refuges, which may also be granted to 'centres containing monuments and other immovable cultural property of very great importance', is established by entry into the International Register of Cultural Property under Special Protection maintained by UNESCO (Hague 1954 Regulations, Article 12; UNESCO 2015).

Hague 1954 (Article 10) further specifies that cultural property under special protection should be marked with the Blue Shield distinctive emblem and are open to international control. The International Register is publically available (UNESCO 2015) and provides, among other things, the location of each refuge and 'centre containing monuments'.

Article 8 indicates that refuges under special protection are established and registered during peace-time. However, 1954 Hague Regulations, Article 11 also provides for internationally recognised ‘improvised refuges’ established under fluid conditions in an armed conflict. These are established by contacting the appropriate Commissioner-General (an international appointee - 1954 Hague Regulations, Article 4) who may authorise the request for up to 30 
days, with the possibility of the refuge subsequently becoming a long-term one by entry in the International Register. It is unclear whether such improvised refuges benefit from special protection in the temporary phase before entry into the International Register. O’Keefe $(2006,156)$ argues not, but also notes that the prescribed marking for an improvised refuge (the Convention’s Blue Shield 'distinctive emblem’ repeated three times) is the same as that of a refuge under special protection, and so indistinguishable by a commander in the field. The Convention's related provisions for protected transport of cultural property distinguish between transport under special protection (Hague 1954, Article 12) and 'transport in urgent cases’ (Hague 1954, Article 13 - when special protection has been applied for, but with insufficient time for the full procedure to be completed). This seems analogous to the distinction between peacetime refuges under special protection and 'improvised refuges'.

It is clear that regular refuges under special protection are intended to shelter the host nation's most important movable cultural property, (O’Keefe 2006, 107-108; 143; Forrest 2010, 98). Hague 1954 also provides for 'ordinary’ refuges for cultural property alongside those under special protection. Article 1's general definition of cultural property includes 'refuges intended to shelter, in the event of armed conflict, the movable cultural property defined [elsewhere in Article 1].’ As such, these benefit from the Convention's normal protections without the requirements for public registration and international control associated with special protection. Like other types of cultural property these 'ordinary' refuges may be marked with a distinctive emblem (Article 6) but this is not required. Nor is publication of their locations, although the Hague Second Protocol of 1999 (Article 5) encourages signatories to prepare inventories of cultural property within their home territories.

The provision for refuges under special protection has not been taken up widely. The International Register records just four current examples (one at Oberried, Germany; one at 
Maastricht and two at Zandvoort, Netherlands); and four whose status was cancelled (AltAussee, Austria; two at Heemskerk and one at Steenwijkerwold, Netherlands). All were established during the Cold War and their cancellations came after its end. There are several reasons why refuges under special protection have not been used more often.

Why are Hague-type refuges under-used? The issue of immunity under special vs. general protection.

One explanation advanced for this limited take-up of refuges under special protection is that it does not provide much (if anything) beyond the general protection afforded by Hague 1954 (O’Keefe 2006, 140-141). The main differences between general and special protection are the international control regime specified for special protection, and the immunity it provides. Hague 1954 Regulations, Article 9 states: 'The High Contracting Parties undertake to ensure the immunity of cultural property under special protection by refraining....from any act of hostility directed against such property.’ It has been argued that this supposedly special 'immunity' is no better than the general protection offered to cultural property by Hague 1954, Article 4.1 ('refraining from any act of hostility, directed against such property'), since neither is absolute, but subject to waiver on grounds of military necessity (O’Keefe 2006, 156-161; Forrest 2010, 99-102). Certainly this distinction was weakened in its drafting for political reasons (O’Keefe 2006, 158). Nevertheless, the distinction remains. The waiving of general protection is only permitted 'in cases where military necessity imperatively requires such a waiver' (Hague 1954, Article 4.2, my italics), whereas withdrawal of immunity under special protection is allowed 'only in exceptional cases of unavoidable military necessity (Hague 1954, Article 11.2, my italics). While the distinction is subjective (O’Keefe 2006, 158-159; Forrest 2010, 100-102) and requires interpretation in specific contexts, it is 
nevertheless not insignificant, as ‘unavoidable’ certainly conveys a more absolute sense than ‘imperative’.

Hague 1954, Article 11.2 continues in more concrete terms. It states that in the case of special protection, the required ‘unavoidable military necessity’ can only be established by an 'officer commanding a force the equivalent of a division in size or larger.' Specifying the command level at which such a decision must be taken reflects Allied Second World War experience and practice to emphasise the gravity of the decision to military personnel. ${ }^{2}$ O’Keefe (2006, 159-160) accepts the importance of this stipulation as 'probably the major substantive difference between general and special protection', but undermines this acknowledgement with the general observation that by 'best practice dictates that a decision to waive the respect owed to generally protected cultural property should also be taken at the highest possible level.' Undoubtedly this is true in principle, but this stipulation of command level is not a feature of general protection in Hague 1954, and so constitutes a significant difference between special and general protection. In fact, Hague Second Protocol 1999 (Article 6b) states that 'the decision to invoke imperative [so general protection - my italics] military necessity shall only be taken by an officer commanding a force the equivalent of a battalion in size or larger, or a force smaller in size where circumstances do not permit otherwise.' This is a significantly lower level of command than the division specified for special protection, and emphasises the intended distinction between special and general protection from a military perspective.

Overall, it seems that the distinction between immunity under general and special protection is underestimated, in great part because their limits have never been tested in practice. And even if its legal significance is as limited as O’Keefe and others claim, it can be argued as of potentially great symbolic importance to governments and armed forces. ${ }^{3}$ Violation of a 
refuge for movable cultural property under special protection undoubtedly would receive greater negative publicity than of a refuge under general protection, and, conversely, the prospect of greater publicity might reduce the risk of a 'special protection' refuge being so violated.

\section{Why are Hague-type refuges under-used? The international control mechanisms}

The other principal reason why special protection under Hague 1954 has not been taken up more widely is the complexity of the international control regime envisaged to implement it, with its bureaucracy, anachronistic emphasis on protecting powers, and right of objection by other parties (Hague 1954 Regulations, Articles 13-16; O’Keefe 2006, 141; 163; 165-169; 200; Forrest 2010, 102-104). Indeed, the only historical attempt to apply for special protection by entry into the International Register during a conflict failed. This was by the Khmer Republic in 1972, for ‘centres containing monuments’ including Angkor, and a nearby refuge for movable cultural property. This failure was due to an objection (perhaps legally invalid) as well as the inherent complexity of the procedure (O’Keefe 2006, 153-154). This complexity is undoubtedly a defect, although it does not necessarily undermine the value of special protection per se. As O’Keefe (2006, 167-168; 178-187) notes, alternative methods for international oversight of Hague 1954, typically involving UNESCO, have evolved since the treaty’s drafting, and there is no particular reason why such methods should not be adapted to oversee and protect refuges under special protection too.

\section{Why are Hague-type refuges under-used? Does enhanced protection supersede special protection for refuges?}


The ‘enhanced protection’ provision of Hague Second Protocol 1999 (Articles 10 to 14) typically is presented as a response to these deficiencies of special protection, although is the Second Protocol does not specify that enhanced protection replaces special protection, and their definitions and procedures are significantly different (Hladik 2000; O’Keefe 2006, 263274; Forrest 2010, 117-121). In particular, the Second Protocol makes no provision for, or reference to, refuges. To a great extent this reflects a contemporary default preference for in situ protection of movable cultural property rather than its evacuation. Enhanced protection facilitates this. Under Hague 1954 (Article 8.1), neither movable cultural property in its own right, nor museums (or galleries, or libraries) housing such cultural property are eligible for special protection unless they house, or are housed in, a refuge, or located in a 'centre containing monuments' under special protection (O’Keefe 2006, 142-143). However, this is not the case for enhanced protection, and so Italy’s recent application for enhanced protection for the National Central Library of Florence was accepted (UNESCO 2018, 15-18). While O’Keefe (2006, 162-163) and others are right to stress the practical advantages of protection in situ, the Second World War experience discussed below demonstrates that it is a mistake to assume that this is always the safest option. Decisions to evacuate or protect in situ should be made based on local circumstances and the nature of the conflict, which are not necessarily predictable. Hague 1954's provisions for refuges under special protection, based on wartime experience, should not be ignored on the assumption that enhanced protection renders them obsolete.

Why are Hague-type refuges under-used? The perceived risks of publically-known refuges.

A final reason why the refuge provisions of Hague 1954 have not been more widely used relates to the perceived advantages of secret refuges over the publically advertised ones required by special protection. Concentrating one’s most valuable movable cultural property 
in known, marked, locations perhaps makes it more (rather than less) vulnerable to attack and misappropriation (Hladik 2000). In essence, refuges become targets rather than shelters. This quandary is more typically associated with inventories of cultural property. For example, Croatian and Bosnian heritage communities certainly thought (rightly or otherwise) that inventories available to Yugoslav federal authorities during Balkan conflicts were used to target their cultural property, including the contents of the Vukovar Museum, removed to Novi Sad in Serbia (Bevan 2016, 58; Walasek 2015, 53). This is a legitimate concern whose risks must be evaluated when states consider cultural property protection policies and procedures. However, as the case studies below show clearly, secrecy carries its own risks. And while the weaknesses of the provisions for refuges in Hague 1954 are less significant than often is claimed, Hague-style refuges retain numerous advantages over the alternatives illustrated below, and so retain their relevance.

\section{Historical Case Studies.}

More widely used alternatives to the publically-known, internationally-protected, refuges envisioned in Hague 1954's special protection regime include in situ protection of cultural property or dispersal to refuges in locations that are secret and (usually) non-urban. In the Second World War, most European combatant nations employed both approaches. Parts of London's collections were protected in situ in museums and galleries, and in underground railway tunnels. Other, movable, items were evacuated to dispersed refuges in country houses, and some (eventually) to purpose-built shelters in quarries in Somerset and Wales (Nicholas 1995, 51-53; 94-96; McCamley 2003; Bosman 2014). However, there are also risks associated with these modes of protection. Even substantial in-place protection may leave cultural property liable to damage from direct bomb hits, and by fire. Besides presenting 
conservation problems, dispersed secret refuges may also become caught up in ground combat and enemy occupation, with all their consequent risks.

Italian experience in the Second World War highlights some particular dangers to dispersed secret refuges and, conversely, some potential advantages of internationally-recognised refuges in advertised locations as provided for by Hague 1954's special protection regime. While Hague-type refuges are currently unpopular for the reasons set out above, these historical lessons suggest that their lack of adoption is problematic, and provide support for their greater use. Much of the actual damage or risk of damage discussed below was primarily a consequence of secrecy, and might have been prevented by the use of publicallyknown refuges.

Italian state policy at the start of the Second World War was that regional fine arts and antiquities authorities were responsible for an appropriate combination of in situ protection and evacuation of collections under their control. Material was prioritised for protection in three categories: 'outstanding artistic value'; 'some artistic value; and remaining works (Subcommission MFAA 1946, 28; Dagnini Brey 2009, 11-19; Scala 2011, 212-214). Precautions were planned on the assumption that bombing was the primary threat, so it made sense to evacuate items judged most important and irreplaceable to non-urban refuges. These refuges were unmarked, and secrecy maintained as much as possible to enhance protection. Typically the refuges were themselves buildings or sites of historic and/or religious importance. Thus items from museums, galleries and churches in Naples were dispersed to official refuges including the Loreto Abbey at Mercogliano and the Abbey of SS. Trinità at Cava de’ Tirreni, as well as historic buildings at Aversa, Calvi Risorta, Caserta, Montecassino, Liveri, Minturno, San Paolo Belsito, Sorbo Serpico, and Teano (Subcommission MFAA 1945c, 21-22; Nicholas 1995, 231; Casiello 2014). 
While evacuation was primarily for protection against bombing, hindsight shows that this in fact caused little damage to Naples’s collections. Damage to the city’s National Museum was largely confined to broken glass, and scaffolding and sandbags provided effective in situ protection for remaining objects. However, other nearby historic buildings, notably the church of Santa Chiara, were severely damaged by bombing, and only good luck spared Naples’ museums and galleries. In situ protection was not always the safest option. Other museums and galleries in Italy certainly were damaged or destroyed by bombing, notably the on-site museum at Pompeii in August 1943 (Subcommission MFAA 1945c, 4; García y García 2006, 173-205), and the museum at Ancona. An Allied report (Subcommission MFAA 1946, 21; 29) notes:

Ancona was two-thirds demolished together with the entire rich Prehistoric collection, of which, quite inexcusably, only a few selected objects had been moved to safety. This was undoubtedly the worst archaeological casualty in Italy, and one of the severest losses in any field......The decision of the Superintendent of Antiquities of Ancona to leave ninety-nine per cent of his exhibits in situ within two hundred yards of a busy port is incredible.

However, the existing evacuation policy was not invariably safer than protection in situ. When Italy became a theatre of ground combat in September 1943, the safety of dispersed refuges was diminished, and secrecy surrounding their locations became as much a liability as a protection.

Stated Allied policy was to spare Italian cultural heritage within the limits of military necessity (Subcommission MFAA 1946, 42; Nicholas 1995, 231-238). US and British Civil Affairs Officers and specialist Monuments, Fine Arts and Archives officers (MFAA 
'Monuments Men') were provided with maps and inventories of cultural property prepared by American civilian academics (Nicholas 1995, 203-227; Coccoli 2017). However, locations of refuges for movable cultural property remained largely unknown to them until they were overrun by Allied ground troops or Allied authorities were notified by Italian officials. As late as March 1944, a key Allied policy document could only warn military personnel to watch out for refuges and report them:

In addition to the monuments etc. mentioned in the lists, there are known to exist repositories to which the more valuable treasures of museums and galleries have been removed for safety. The sites of such repositories are not at present known. When found they are to be treated as starred [i.e. protected] monuments, and their location reported. (HQ AAI 1944)

A number of factors cause damage to cultural property in war zones. Their definition varies in scholarly literature (Stone 2016 identifies seven), but four in particular were relevant to Italy in the Second World War. These were: damage by careless occupation and military use of cultural sites; deliberate damage by combatants; accidental and collateral damage during combat (including bombing and artillery); and damage by military or civilian looting. The following case studies show how secret dispersed refuges in wartime Italy exposed (or potentially exposed) the cultural property they contained to each of those risk categories.

\section{Risk of Damage by Careless Military Occupation: The Castel del Monte Refuge for Puglia.}

The primary refuge for collections in Puglia was the medieval fortress of Castel del Monte, in mountains c. $50 \mathrm{~km}$ west of Bari. Some 260 crates of art, antiquities and library materials controlled by the regional superintendencies and from churches in Puglia were stored on the 
castle’s ground floor (HQ AAI, 1944). The castle itself was listed in Allied inventories as a 'two-star' site although its function as a refuge initially was unknown. ${ }^{4}$ The area was occupied by British forces in September 1943, fortunately without combat (Molony 1973, 344-347, Map 17), since Castel del Monte 'could hardly have failed to have suffered in the event of serious fighting south of Foggia' (Subcommission MFAA 1946, 14). Because the refuge was unknown to MFAA personnel, no objections were made to the castle's requisition and occupation by a Royal Air Force unit. Requisition was made without regard to the castle’s contents, with military personnel 'quartered indiscriminately throughout.' Besides the possibility of theft, the main risk was fire, since field ovens were constructed against courtyard walls adjacent to rooms storing the evacuated collections. Fortunately damage to the castle was 'limited to blackening and general squalor', but the British monuments officer who eventually inspected the repository (late January 1944) noted it was only by luck that it escaped serious fire damage (Ward Perkins 1944). By the time of Ward Perkins’s visit, the RAF had moved on, but the castle remained occupied by a US Army Air Force detachment. The Americans used only part of the castle, so risk of damage was reduced, although occupation by a new unit might have reinstated those risks. Subsequently, classification of the site in Allied inventories was raised to three stars to reflect the presence of the refuge. ${ }^{5}$

In this case, the refuge was at risk because at the time of military requisition, it was unknown to Allied authorities charged with protecting cultural property by controlling occupation of historic buildings by military personnel. The MFAA eventually learned of the refuge through Italian heritage authorities. However notification took some four months, as MFAA personnel were spread very thinly, without recognised channels by which such information could be disseminated. Had they known about the refuge earlier, they might have objected to the requisition. This occurred in the case of Mercogliano’s Loreto Abbey refuge for 
Neapolitan collections. MFAA officers knew of the refuge located in the Abbey buildings, so their attempted requisition by Canadian forces in December 1943 was refused (Gardner 1944, 3). However, once a military unit occupied an historic building, it was difficult to get the requisition lifted, as shown by the National Museum in Naples, occupied by a British medical unit from November 1943 to June 1944, despite MFAA opposition and a recommendation by a military Commission of Enquiry to de-requisition it (Collier Commission 1944, 4; 21).

\section{Deliberate Damage by Combatants: The Destruction of the San Paolo Belsito Refuge of the Archivio di Stato di Napoli.}

There were thankfully few instances in wartime Italy in which cultural property was the primary target of deliberate damage or destruction by combatants, not least because both Germans and Allies presented themselves as protectors of Italian (and Western) cultural heritage against a barbaric enemy (Nicholas 1995, 231; 239-245; Klinkhammer 2012; Moll 2012). However, dispersed and unprotected refuges in unpredictable and insecure wartime conditions are vulnerable to vengeful combatants. The clearest and worst example in Italy was the burning of the Villa Montesano at San Paolo Belsito near Nola by German soldiers on 30 September 1943. Italian authorities had stored materials evacuated from the Neapolitan State Archive, 866 cases containing some 30,000 volumes and 50,000 parchments, including medieval documents of immense historical value (Filangieri 1944, 252-255; Subcommission MFAA 1945c, 19). According to the archive's director who was present, the villa's contents were communicated and explained to local German troops by archive staff, but nevertheless they were deliberately burned in revenge for the killing nearby of a German soldier. Only 108 cases were saved. 
Intentional damage to cultural property in an active theatre of conflict is difficult to prevent, and, as noted, publicising locations of refuges may make them easier to target. However, even in this example of deliberate damage, a regime of international protection and wider knowledge of the refuge's location might have prevented its destruction. Contemporary accounts suggest the destruction was a local initiative by soldiers and junior officers, and only local German forces knew of the refuge and its contents. Its destruction ran contrary to German strategic interests as self-proclaimed protectors of western heritage. If the refuge’s location had been known to higher headquarters, it would have been to their advantage to secure and protect it from their own troops. Likewise, even symbolic international protection may deter destruction and looting, provided combatants have an interest in adhering to internationally-recognised norms of behaviour.

\section{Accidental and Collateral Damage in Combat: The Montecassino Refuge and the Refuges for Florence.}

Like Mercogliano, Cava de’ Tirreni and other sites, the Benedictine Abbey of Montecassino served as a refuge for movable cultural property from collections in Naples. Materials (187 crateloads) were evacuated there in June to September 1943 on the authority of Amedeo Maiuri, archaeological superintendent for Campania, and Bruno Molajoli, Superintendent of Galleries (Subcommission MFAA 1945c, 18; Dagnini Brey 2009, 21-22; Casiello 2014; Gentile-Bianchini 2015, 32-35; 147-154). Most came from Naples’ National Museum, which housed the majority of the city’s important paintings and archaeological collections including materials from Pompeii and Herculaneum.

This made sense for protection against bombing, since the Abbey was unlikely to be targeted for its own sake. At the time most of the materials were evacuated (9-10 September 1943) 
several historic buildings in Naples had been damaged by bombing, although Allied landings on the Italian mainland Italy (from 3 September) provided a warning that even refuges away from major urban centres might be affected by combat. By early 1944, Montecassino Abbey lay on the front line, as the hill on which it stood formed a key point in the German defensive system of the Gustav Line. The Abbey was destroyed by Allied bombing on 15 February 1944 (Molony 1973, 691-714). In fact, by then its contents were largely safe in Rome, but its deficiencies as a refuge and Allied uncertainties about the location of the evacuated materials placed them at considerable risk.

Initially on their entry into Naples in October 1943 Allied MFAA personnel were uncertain of the location and status of the materials evacuated from Naples (Norris n.d.). ${ }^{6}$ However, a report dated 1 December 1943 notes efforts to protect the Abbey from damage in combat because of its 'importance and contents' [my italics] (Gardner 1943, 2). In fact, the movable art and antiquities had been evacuated from the Montecassino refuge by German forces in October 1943, initially to their headquarters at Spoleto, and then to Rome in two consignments, arriving at the Castel Sant'Angelo on 8 December 1943 and the Palazzo Venezia on 4 January 1944 (Subcommission MFAA 1945a, 3-4; 1945c, 18-19; 1946, 12; Nicholas 1995, 240-245; Dagnini Brey 2009, 28-31; Gentile-Bianchini 2015, 49-61; 63-68). Their arrivals were announced in Axis media and known to the Allies, but considerable uncertainty remained regarding the reports' validity, so that, when the Abbey was bombed in February 1944 (according to British monuments officer John Ward Perkins) 'we did not know [the "Neapolitan treasures”] had been moved, although we hoped they had'.

Ultimately the contents of the Montecassino refuge survived, but after considerable risk, and their survival was partly due to luck. There were two major problems with the Abbey as a refuge. One was the secrecy surrounding its use as a refuge, and of the movements of the 
collections stored there. In this instance, wider knowledge of the refuge's function and evacuation of its contents under international protection would have helped protect it rather than put it at further risk, since the Allies had a vested interest in ensuring its survival. International knowledge and supervision of the refuge, its evacuation and transport would also have avoided the risk of entrusting its protection solely to German military authorities. For while their intervention ensured that the contents of the refuge were safe from Allied bombing, elements of the Hermann Göring Division overseeing the evacuation misappropriated some items (see below).

The second, more serious, problem is that the militarily important location of Montecassino Abbey made it unsuitable as a refuge once Italy became a theatre of land warfare. Under Hague 1954’s provision for special protection, Montecassino Abbey might have been declared a refuge under special protection and so immune, but at the price of de-militarisation of the refuge (the Abbey itself) and its surroundings, including nearby transit routes (Hague 1954, Articles 8.1; 8:5; 9). ${ }^{8}$ In fact, O’Keefe et al (2016, §§130-132) specifically cite the relationship between Montecassino Abbey and the Gustav Line in 1944 as an historical example in arguing that current Laws of Armed Conflict forbid military use of the ‘immediate surroundings’ of protected cultural property. A similar issue was addressed before the 1959 grant of special protection to the Vatican City as a 'centre containing monuments'. This required agreement by Italian authorities to move or de-militarise elements of military and transportation infrastructure close to the boundaries of the Vatican City (Boylan 1993, 55-56 incl. n. 13; O’Keefe 2006, 150; UNESCO 2015, 11).

In general, such militarily important locations should not be used as refuges, and the special protection stipulations of Hague 1954 seek to limit their use. Undoubtedly the example of Montecassino influenced its drafting. Application of those principles (had they been 
established by 1943) would have discouraged Italian authorities from using Montecassino as a refuge in the first instance, by forcing them to demilitarise its hinterland, something that seems unlikely given its strategic importance. If, nevertheless, a refuge under special protection had been established in the Abbey, it would have been immune from attack, but that immunity would have pertained only so long as defending forces made no use of the refuge or its surroundings for military purposes. Finally, the special protection regime provision for internationally supervised evacuation of 'at risk' cultural property might have been valuable at Montecassino as protection against accidental air attack on transporting vehicles and theft by military personnel.

Like collections from Naples, movable cultural property from Florence and Rome was evacuated to secret dispersed refuges, primarily to protect it from air attack. For example, there were some 40 extra-urban refuges for Tuscany (Subcommission MFAA 1945b, 50-53). However, in late 1943 the Rome collections were re-concentrated in Rome and the Vatican, limiting the damage done to them by ground combat and tactical bombing during the Allied advance in the spring and early summer of 1944 (Nicholas 1995, 241-243; Forti 2014). A contemporary Allied report lists eight official deposits for Rome and Lazio, noting that their contents were moved to Rome and/or the Vatican by June 1944 except for two (Capraola and Tivoli) that remained, and one (Gennazzano) evacuated to Milan by the Germans (Subcommission MFAA 1945d, 28-30). Collections from 24 other central Italian towns were also concentrated in Rome and the Vatican at this time, sometimes with paradoxical but fortuitous results. The Palazzo Vitelleschi museum in Tarquinia had initially served as a refuge for Rome collections, hosting eight cases of antiquities from the capital. Subsequently these were returned to Rome (Villa Giulia museum) for safety along with 24 cases of antiquities from the Tarquinia Museum itself. This was fortunate, since the Palazzo 
Vitelleschi later was badly damaged by tactical bombing (Subcommission MFAA 1945d, 24; 30; 32).

In contrast, collections from Florence remained mostly in dispersed refuges through the summer of 1944, even as Allied land forces (with tactical air support) advanced north from Rome. While the Allies' decision not to bomb Florence itself and precautions taken in bombing targets nearby made the city safer than its hinterland, contents of only six refuges were wholly or partially returned to Florence, as the necessary vehicles and fuel were in use by German forces (Subcommission MFAA 1945a, 2-4; Nicholas 1995, 251; Dagnini Brey 2009, 31-35). By mid-June, it was generally considered dangerous to move contents of other refuges back to Florence, although the Oliveto (Castello Guicciardini) deposit was returned on 17 July (Subcommission MFAA 1945a, 3-4). Refuges with contents remaining included the Sitwell villa at Montegufoni (c. $18 \mathrm{~km}$ south-west of Florence) and two refuges at Poppiano, 2km further south. Like Montecassino previously, these refuges now lay in a theatre of ground combat as the Eighth Army advanced on the lower Arno west of Florence, according to an Allied strategy of encircling rather than directly attacking the city (Jackson and Gleave 1984, 87-96, Map 5).

Throughout July, confusion on the part of both Allies and Germans regarding the locations and status of unevacuated refuges put them at risk of damage from combat and unsupervised military occupation. Neither the German art protection organisation (Kunstschutz) nor their Army Group Headquarters possessed complete lists of the refuges until 15 July (Subcommission MFAA 1945a, 6; Nicholas 1995, 252), perhaps due to Italian concerns these would be used to target deposits for looting. A contemporary Allied report states that locations of refuges had been known to the Allies since the liberation of Rome in June 1944, but it was believed that their contents had been returned to Florence by July: 
The presence of the great works of Art [sic] from Florence museums and churches still in highly exposed positions came therefore as a considerable surprise. (Hartt 1944, 1; Subcommission MFAA 1946, 13)

The Italian resistance in Florence (including Cesare Fasola, Uffizi librarian) sought to notify the Allies, but the contemporary Allied report notes that this information was not received at least by ‘responsible... authorities’ (Hartt 1944, 4; Dagnini Brey 2009, 37-38).

Consequently:

Some of these deposits, of which a list had fortunately been obtained earlier, were found on arrival empty, or nearly so; others turned up of which the Allies had known nothing whatever. (Subcommission MFAA 1945b, 3)

The best documented 'discovery' of a Florentine art refuge by the Allies was that of the Sitwell villa at Montegufoni, because BBC correspondent Wynford Vaughan-Thomas and writer and serving British Army officer Major Eric Linklater were responsible for its recognition (31 July 1944). Vaughan-Thomas broadcast the discovery on BBC Radio (Imperial War Museum sound recording 1502) and included a vivid and entertaining account in his later memoir (Vaughan-Thomas 1967). There is also a more sober official account by MFAA officer Lt. Frederick Hartt (Hartt 1944, 1-3; Subcommission MFAA 1946, 12-14; see also Hartt 1949, 16-22; Nicholas 1995, 259-262; Dagnini Brey 2009, 112-117; 122-130).

Vaughan-Thomas and Linklater had gone to conduct interviews at the villa, occupied as a forward observation post by Indian troops with British signallers. It lay within 2500 yards of the front line, was under sporadic artillery fire and had been occupied by German troops 
before changing hands. According to Vaughan-Thomas (1967, 126-127), an Italian civilian sheltering there alerted him to uncrated pictures stacked in a darkened room (Figure 1):

As he opened each shutter a shaft of sunlight shot down, like the spots in a theatre, and lit up the frames. Down shot the first shaft - and I gave a gasp of delight and astonishment. There before me was one of the world's greatest paintings, Botticelli’s ‘Primavera’. Down came the second shaft: Again a glorious revelation - Uccello’s 'Battle of San Romano.' On through the hall, with shaft after shaft of the sun lighting up picture after picture, Giottos, Cimabues, Andrea del Sartos, Lippo Lippis - the greatest concentration of superb painting I had ever seen.

The civilians also fetched Cesare Fasola, the Uffizi librarian, who had come from Florence in early July in a personal effort to protect Montegufoni and neighbouring refuges, interceding for them with occupying German troops. Fasola’s courage and initiative are praised in contemporary Allied documents (Hartt 1944, 1; Subcommission MFAA 1945b, 7; Nicholas 1995, 259-260; Dagnini Brey 2009, 117-122). Fasola informed Vaughan-Thomas and Linklater of other refuges nearby, including Poppiano and Montagnana. British higher command was notified, guards were posted and eventually their contents inventoried and returned to Florence. Little damage was done to the pictures at Montegufoni, and that by movement and handling. However, this was down to good luck. The war essentially passed over Montegufoni, and the refuge was fortunate to escape Allied and German artillery fire, and tactical bombing. It was also fortuitous that there was no significant accidental damage or theft by occupying troops of either side, or civilians. 
The Villa Guicciardini refuge at nearby Poppiano suffered more than Montegufoni, although it too was fortunate not to suffer catastrophic damage given the proximity of fighting. Hartt relates that its contents were 'treated...somewhat roughly', and, more significantly, the villa was hit by an artillery shell. Most paintings had been crated up and were undamaged, but:

\author{
Unfortunately the great Visitation by Pontormo from Carmignano had been \\ thrown down on the floor reputedly by Allied troops, and thus received the full \\ weight of the ceiling when it fell; furthermore the soldiers had walked on it later, \\ rubbing the plaster into the surface and removing considerable areas of paint. \\ This may be considered the only badly damaged work of art in any of the \\ deposits. (Figure 2; Hartt 1944, 2; Hartt 1949, 22)
}

Minor damage occurred to other paintings at Poppiano, including some allegedly used by New Zealand troops as cots (Hartt 1944, 2; Subcommission MFAA 1946, 12-14).

Like the Naples materials sent to Montecassino, the movable works of art in Tuscan refuges survived largely unscathed, but due to luck rather than the evacuation policy or the refuges themselves. While the risks at Montegufoni and Poppiano were less dramatic (in retrospect) than at Montecassino, artillery fire from either side could easily have destroyed a substantial concentration of important Florentine art. The existence of advertised refuges as envisaged by Hague 1954 would have made their locations known to commanders and cultural protection personnel on both sides, all with a vested interest in protecting the art they contained. The problems of dissemination of information shown in this case study would have been greatly reduced. Open knowledge of refuge locations would have made it impossible for the war to pass over them, with all its attendant risks, and the Hague 1954 Regulations also provide for controlled emergency evacuation of the contents of a threatened refuge. 


\section{Looting, Theft and Misappropriation of Cultural Property: Montecassino and the Florentine Refuges Again.}

Our fourth potential cause of damage or loss of cultural property is looting, theft and other misappropriation by troops or civilians. The possibility of theft from unsecured refuges by occupying troops and/or civilians has already been mentioned. However, the treatment of the Naples collections after their evacuation from Montecassino, and of contents of some of the Tuscan refuges, provide clear examples of the vulnerability of dispersed secret refuges to misappropriation, in each case by German troops and military authorities.

As noted, Naples collections moved to the Abbey at Montecassino were evacuated in October 1943 by the Luftwaffe division ‘Hermann Göring’, arriving in Rome in December 1943 and January 1944. In the meantime the cases of material were kept at the Division's headquarters near Spoleto in Umbria, allegedly for lack of transport. Requests for access by Italian authorities were refused, while German officials (including their Kunstschutz) were allowed by 'this politically powerful and somewhat independent Division' to visit but not to inventory (Subcommission MFAA 1945a, 4). When crates eventually arrived in Rome, fifteen were missing. Italian authorities were told that two transporting trucks had been delayed by machine-gun fire. In fact they never arrived, and while the missing items were soon identified from inventories , their whereabouts remained unknown for nearly a year. In fact the missing crates were sent to Berlin by officers of the Göring division, allegedly as a birthday present for their patron. They never reached him, but ended up in the art refuge at Alt-Aussee in Austria, to be discovered by US troops at the end of the war and subsequently returned to Naples (Subcommission MFAA 1945c, 18-19; Nicholas 1995, 314; 436; 438; Dagnini Brey 2009, 260-261; Gentile-Bianchini 2015, 89-93). The stolen material included bronze sculpture from Pompeii (Apollo) and the Villa of the Papyri at Herculaneum (a deer and a 
female dancer) and numerous paintings, including Titian’s Danae and Lavinia, Raphael’s Madonna of Divine Love and Breughel's Blind Leading the Blind.

Misappropriation of these materials from the Montecassino refuge provides a clear example of looting by combatants. Appropriation of art by the Germans from some Tuscan refuges provides less clear-cut examples, with individual motives ranging from rapacity to (perhaps) over-zealous (and unauthorised) protection (Subcommission MFAA 1945a, 4-19; 1945b, 3-4; 50-53; 1946, 14-16; Nicholas 1995, 252-255 ). ${ }^{9}$ Regardless, this appropriation was undertaken against the wishes of Italian civilian authorities, and the final result looked very much like looting. While some Florentine materials remained in refuges to be discovered by the Allies (above), others were removed by German military personnel. As noted, the contents of Oliveto (Castello Guicciardini) refuge were partially returned to Florence on $17^{\text {th }}$ July 1944 by the German $71^{\text {st }}$ Infantry Regiment. However, paintings including Filippo Lippi’s Annunciation, were left in the refuge and found by MFAA officer Frederick Hartt a month later (Hartt 1944, 2-3). Two other paintings, Cranach’s Adam and Eve were:

separated from the rest [by $71^{\text {st }}$ Infantry Regiment] because they were 'Germanic art' and could not be exposed to the danger of being returned to FLORENCE, though LANGSDORFF [Kunstschutz Director in Italy] admitted that it was the Regt.'s intention to take them to GERMANY.

Langsdorff secured these paintings for a receipt stating that he would take them to Germany himself (Subcommission MFAA 1945a, 7). It is likely that $71^{\text {st }}$ Infantry Regiment intended to send the Cranachs to Germany. Langsdorff's motives are unclear and have been debated. In the first instance, he may have lied to secure them to protect them from $71^{\text {st }}$ Infantry Regiment. However, he subsequently failed to inform Giuseppe Poggi (Superintendent of 
Galleries in Florence, who had noted the Cranachs’ absence) , and instead of returning them to Florence, sent the pictures to German Military Government Headquarters at Verona, whence they were removed eventually to South Tyrol with other art from Florentine refuges (see below).

The Montagnana (Villa Bossi-Pucci) refuge had already been evacuated to a location near Bologna on 3 July 1944, at the initiative of the German army’s $362^{\text {nd }}$ Infantry Division, even before the German garrison commander had warned Poggi that the refuge was in danger from the Allied advance and advised that its contents should be evacuated beyond the Apennines. Poggi objected that if the contents of refuges were to be moved, they should go to Florence itself. Only subsequently was he informed of the fait accompli. This may well have been a genuine attempt at protection by the Germans, since once the materials had been moved, Army Group Headquarters sought to place them in the protection of Italian church authorities, an offer refused for suspicion of German motives (Subcommission MFAA 1945a, 6-7).

Materials from other refuges were evacuated north in late July 1944 on the initiative of Kunstschutz director Langsdorff, again over-riding Poggi’s objections. Twenty-six crates of sculpture from the Dicomano refuge were sent to German headquarters at Verona, along with all or some materials from refuges at Poggio a Caiano, Poppi and Soci (Subcommission MFAA 1945b, 52-53; Dagnini Brey 2009, 224-228). By September 1944, on the orders of General Karl Wolff, senior SS officer in Italy, all material taken from the Florentine refuges (532 paintings and 153 cases of sculpture) was moved on to San Leonardo near Merano and Campo Tures, near Brunico. Both lay in what Italians considered Alto Adige. However, after the 1943 armistice this area was administered directly by German authorities, as part of Reichsgau Tirol-Vorarlberg, beyond the effective influence of officials of the Italian Salò 
regime. These officials sought unsuccessfully to have the collections moved to their own refuges in northern Italy, but were denied access, and they remained under German control until surrender to the Allies (Subcommission MFAA 1945a, 8-19; Nicholas 1995, 254-257; Dagnini Brey 2009, 229-240; 244-245). Whatever the original motives of German troops and Kunstschutz officials in evacuating the refuges, the Allied view seems reasonable, that by September 1944 the concentration of their contents in Alto Adige meant there was no intention of returning them to Italy or Italian authorities, and they could easily be transferred across the Alps (Subcommission MFAA 1946, 16). These collections (along with Kunstschutz personnel including Langsdorff) remained in their final refuges at San Leonardo and Campo Tures until surrendered to the Allies at the end of the war (Figure 3). Allied authorities returned them to Florence in July 1945 (Subcommission MFAA 1946, 16; Nicholas 1995, 268-272; Dagnini Brey 2009, 238-239).

Thus German treatment of Florentine refuges reveals a range of activities from small-scale theft and large-scale looting to alleged protective evacuation, and their motives have been debated ever since. However, it seems likely that organised and known refuges such as those envisaged by Hague 1954 would have mitigated some of the risks to the Florentine collections. Known refuges rather than secret ones would have obviated the initial risk of combat damage and so removed possible pretexts for their contents’ removal by German troops. Similarly, a regime of international observation and control would have strengthened the position of Italian heritage authorities relative to the Germans, provided for the possibility of supervised evacuation of threatened refuges, or at least, in the worst case, facilitate what O’Keefe $(2006,187)$ characterises as ‘the mobilisation of shame’ against abuses.

\section{Conclusion}


In creating policies to safeguard cultural property in future conflicts, nations inevitably balance potential risks against the diverse and sometimes even incompatible advantages of various means of protection. In the Second World War aerial bombardment of urban centres was perceived, not unreasonably, as a major threat to cultural property, and a common response was evacuation of movable collections to dispersed, secret, non-urban refuges. In many situations (for example, the London collections discussed in McCamley 2003), this was an effective measure that protected them. However, in Italy, the secret character of such refuges put their contents at risk in areas of ground combat. Some of these risks are potentially increased in modern conflicts, both conventional wars between nation states (as in the Italian examples - and presumably the circumstances foreseen by European states establishing ‘special protection’ refuges during the Cold War) but also in modern civil conflicts. Dissemination of news and images by private individuals using modern communications technology and social media make it less likely now than in the Second World War that truck convoys of cultural property could be evacuated to refuges while remaining secret. It would be better to eschew what the historical case studies show to be the doubtful advantages of secret refuges for the potential advantages of publicity and international supervision. Multiple dispersed refuges are also potentially difficult to secure, particularly in the event of internal conflict and civil unrest. In many circumstances, a limited number of internationally known and supervised refuges will offer greater safety.

Another option for protection of movable cultural property under recent consideration is evacuation to 'safe havens' beyond the territory of the owning state (Paumgartner and Zingg 2018). Under certain circumstances this option has advantages, and its discussion emerged primarily from the severe breakdown in security and authority seen, for example, in Da'eshcontrolled areas of Syria and Iraq. However, extra-territorial safe havens also have some 
disadvantages of national refuges, and some additional ones besides. Besides the common problems of transporting cultural property to a safe location (whether a secure refuge within a state's borders, or a route to a safe haven beyond them) they raise issues relating to ownership and control of cultural property stored in a third-party state, and of who has authority to evacuate and subsequently repatriate that cultural property. It is clear that extraterritorial refuges should be used only be a last resort (Paumgartner and Zingg 2018, 326; 330-345). For this reason, UN Security Council Resolution 2347 (2017) ‘encourages Member States to take preventative measures to safeguard their...cultural property...in a network of “safe havens” [i.e. refuges] in their own territories’ [my italics].

Under these circumstances, the provisions for refuges in Hague 1954 deserve to be given more attention, and to be used more widely. The wartime experience discussed in this paper certainly provides evidence for the potential disadvantages of secret refuges, and, conversely, some general advantages of Hague-type publically advertised refuges. Beyond this issue of secret vs. publically advertised refuges, the specific provision for special protection refuges in Hague 1954 should not be dismissed as readily has been the case in recent decades for the most part. While the application of special protection to 'centres containing monuments' remains problematic, with regard to refuges, special protection has not been superseded or replaced by the enhanced protection of the Second Protocol. And, while the specific international control mechanisms for special protection set out in the Hague 1954 Regulations are undoubtedly cumbersome and obsolete, these can be adapted and updated, and the general principle of international control remains valid and important. Similarly, the immunity of cultural property under Hague 1954's special protection regime is stronger than generally argued, based as it is, on the experience of the Second World War. 


\section{Notes}

1. Following the terminology of Hague 1954, I use 'refuge' to denote shelters for movable cultural property, although wartime documents typically use 'repository' or 'deposit'.

2. See, for example, HQ AAI (1944) of 30 March 1944, requiring decisions on military occupation of buildings of particular historical importance to be taken at divisional level or above. In almost all the Second World War case studies in this paper, had the existence of a refuge been brought to the attention of a commander at divisional level or above, it would have been at less risk of incidental damage.

3. Protection of historic buildings, monuments and museums was rooted in the same legal provision - Hague Convention (IV) 1907 - throughout the Second World War. However, aspects of Allied treatment of cultural property changed even while the law remained the same, in great part due to greater awareness of the problems among service personnel instigated by publicity and symbolic/public statements such as Eisenhower's famous 29 December 1943 letter to commanders on Historical Monuments (Nicholas 1995, 237-238).

4. American Defense - Harvard Group (1943, 3): 'Castel del Monte: castle **. Castle del Monte (Mountain Castle) of Frederick II, the finest castle in Italy, recently restored.’ The ** indicated the monument's importance as judged by academics compiling the inventories, with other monuments ranked from *** (most important) to listed (so still relatively important) but with zero stars. The castle is now on the UNESCO World Heritage List.

5. By 30 March 1944. See Lists of Protected Monuments: Apulia, appended to HQ AAI (1944): 'Castel del Monte (Bari), O9078. *** castle with deposits of art objects from Apulia.'

6. Norris’s list is undated but is probably part of a report he wrote before 1 October 1943.

7. Unpublished letter of 16 September 1977 from Ward Perkins to author David W. Richardson (British School at Rome War Damage Documents collection, Box B). 
8. At Montecassino, the situation was further complicated by the fact that the armed forces using the surroundings of the Abbey for military purposes were those of a third party (Germany).

9. Subcommission MFAA 1945a, 4-19 provides the most complete contemporary account, written in June 1945 by MFAA officers Douglas Cooper (British) and Ernest T. de Wald (US) from interrogation of Kunstschutz personnel. 


\section{References}

NARA refers to documents in the US National Archive.

TNA refers to documents in the UK National Archives.

American Defense - Harvard Group. 1943. American Defense - Harvard Group, Committee on Protection of Monuments. List of Monuments in Italy: Region of Apulia. NARA M1944, RG 239/0098.

Bevan, Robert. 2016. The Destruction of Memory: Architecture at War. London: Reaktion Books.

Bosman, Suzanne. 2014. “Un museo sotto una montagna: la dimora della National Gallery in tempo di guerra.” In Musei e monumenti in guerra 1939-1945: Londra, Parigi, Roma e Berlino, edited by Teresa Calvano and Micol Forti, 79-100. Vatican City: Edizioni Musei Vaticani.

Boylan, Patrick J. 1993. Review of the Convention for the Protection of Cultural Property in the Event of Armed Conflict (The Hague Convention of 1954). London: City University.

Casiello, Stella. 2014. "Prevenzione, ricostruzione e restauri a Napoli e in Campania: Criteri, metodi, esperienze.” In Musei e monumenti in guerra 1939-1945: Londra, Parigi, Roma e Berlino, edited by Teresa Calvano and Micol Forti, 250-262. Vatican City: Edizioni Musei Vaticani. 
Coccoli, Carlotta. 2017. Monumenti violati. Danni bellici e riparazioni in Italia nel 19431945: Il ruolo degli Alleati. Florence: Nardini Editore.

Collier Commission. 1944. Report by the Allied Commission of Enquiry Appointed to Investigate Damage Alleged to have been Caused to Real and Personal Property of Historical and Educational Interest in Italy. NARA M1944 RG 239/0062.

Dagnini Brey, Ilaria. 2009. The Venus Fixers. New York: Farrar, Straus and Giroux.

Filangieri, Riccardo. 1944. "Report on the Destruction by the Germans, September 30, 1943, of the Depository of Priceless Historical Records of the Naples State Archives." The American Archivist 7 (4): 252-255.

Forrest, Craig. 2010. International Law and the Protection of Cultural Property. London: Routledge.

Forti, Micol. 2014. “ 'I trasporti possono iniziati da oggi, 15 novembre 1943’: Il ruolo del Vaticano nella salvaguardia del patrimonio artistico italiano.” In Musei e monumenti in guerra 1939-1945: Londra, Parigi, Roma e Berlino, edited by Teresa Calvano and Micol Forti, 149-165. Vatican City: Edizioni Musei Vaticani.

García y García, Laurentino. 2006. Danni di guerra a Pompei: Una dolorosa vicenda quasi dimenticata. Rome: "L’Erma” di Bretschneider. 
Gardner, Paul 1943. Major Paul Gardner, HQ Region 3 Allied Military Government. November Report of the Division of Education and Fine Arts, 1 December 1943. NARA M1944 RG 239/0067.

Gardner, Paul 1944. Major Paul Gardner, HQ Region 3 Allied Military Government. December Report of the Division of Fine Arts, 10 January 1944. NARA M1944, RG 239/0067.

Gentile, Benedetta, and Francesco Bianchini. 2015. I misteri dell'Abbazia: le verità sul tesoro di Montecassino. Florence: Casa Editrice Le Lettere.

Hartt, Frederick. 1944. $2^{\text {nd }}$ Lt. Frederick Hartt, Allied Military Government, Office of the Monuments and Fine Arts Officer, Region VIII. Report on Deposits of Works of Art. RVIII/31/MFAA/10.1. 22 August 1944. TNA T209/17/2.

Hartt, Frederick. 1949. Florentine Art under Fire. Princeton: Princeton University Press.

Hladik, Jan. 2000. “Reporting system under the 1954 Convention for the Protection of Cultural Property in the Event of Armed Conflict”. International Review of the Red Cross 840.

https:/www.icrc.org/en/doc/resources/documents/article/other/57jqtd.htm.

HQ AAI. (1944). Headquarters Allied Armies Italy (Administrative Echelon), Administrative Instruction No. 10: Preservation of Property of Historical or Educational Importance in Italy, 30 March 1944. NARA M1944, RG 239/0067. 
Jackson, General William, and Group Captain T.P. Gleave. 1984. Victory in the Mediterranean Part II: June to October 1944. Vol. VI of The History of the Second World War: The Mediterranean and Middle East. London: HMSO.

Klinkhammer, Lutz. 2012. “Kunstschutz im Propagandakreig. Der Kampf um die Sicherstellung der italienischen Kunstschätze 1943-1945”. In Kunsthistoriker im Kreig: deutscher militärischer Kunstschutz in Italien 1943-1945, edited by Christian Fuhrmeister, Johannes Griebel, Stephan Klingen, Ralf Peters, 49-73. Cologne, Weimar, Vienna: Böhlau Verlag.

McCamley, M.J. 2003. Saving Britain’s Art Treasures. Barnsley: Pen \& Sword Books.

Moll, Martin 2012. “Bildpropaganda der Wehrmacht”. In Kunsthistoriker im Kreig: deutscher militärischer Kunstschutz in Italien 1943-1945, edited by Christian Fuhrmeister, Johannes Griebel, Stephan Klingen, Ralf Peters, 187-205. Cologne, Weimar, Vienna: Böhlau Verlag.

Molony, C.J.C. 1973. The Campaign in Sicily 1943 and the Campaign in Italy, $3^{\text {rd }}$ September 1943 to $31^{\text {st }}$ March 1944. Vol. V of The History of the Second World War: The Mediterranean and Middle East. London: HMSO.

Nicholas, Lynn H. 1995. The Rape of Europa: The Fate of Europe's Treasures in the Third Reich and the Second World War. New York: Vintage Books.

Norris, Christopher. n.d. F-Lt. C. Norris, Schedule of Deposits of Works of Art. NARA M1944, RG 237/0067. 
O’Keefe, Patrick J., and Lyndel V. Prott, eds. 2011. Cultural Heritage Conventions and Other Instruments: A Compendium with Commentaries. Builth Wells: Institute of Art and Law.

O’Keefe, Roger. 2006. The Protection of Cultural Property in Armed Conflict. Cambridge: Cambridge University Press.

O’Keefe, Roger, Camille Péron, Tofig Musayev, and Gianluca Ferrari. 2016. Protection of Cultural Property: Military Manual. Paris: UNESCO.

Paumgartner, Nikolaus Thaddäus and Raphael Zingg. 2018. “The Rise of Safe Havens for Threatened Cultural Heritage.” International Journal of Cultural Property 25: 323-346.

Scala, Barbara. 2011. “In attesa del conflitto: Le opere di prevenzione del patrimonio monumentale italiano.” In Guerra, monumenti, ricostruzione: Architetture e centri storici italiani nel secondo conflitto mondiale, edited by Lorenzo de Stefani, 211-223. Venice: Marsilio Editori.

Stone, Peter G. 2016. “The Challenge of Protecting Heritage in Times of Armed Conflict.” Museum International 67: 40-54.

Subcommission MFAA. 1945a. Headquarters Allied Commission, Subcommission for Monuments, Fine Arts and Archives. Report on the German Kunstschutz (MFA\&A Branch) in Italy Between 1943 and 1945. 30 June 1945. TNA T 209/30/3. 
Subcommission MFAA. 1945b. Headquarters Allied Commission, Subcommission for Monuments, Fine Arts and Archives. Final Report: Tuscany. 7 September 1945. TNA T 209/30/2.

Subcommission MFAA 1945c. Headquarters Allied Commission, Subcommission for Monuments, Fine Arts and Archives. Final Report: Campania. 25 November 1945. TNA T 209/30/1.

Subcommission MFAA. 1945d. Headquarters Allied Commission, Subcommission for Monuments, Fine Arts and Archives. Final Report: Lazio. 5 December 1945. TNA T 209/30/1.

Subcommission MFAA. 1946. Headquarters Allied Commission, Subcommission for Monuments, Fine Arts and Archives. Final Report: General. 1 January 1946. TNA T 209/30/1.

UNESCO. 2015. International Register of Cultural Property under Special Protection. http://www.unesco.org/new/fileadmin/MULTIMEDIA/HQ/CLT/pdf/Register2015EN.pdf

UNESCO. 2018. Second Protocol to the Hague Convention of 1954 for the Protection of Cultural Property in the Event of Armed Conflict. Committee for the Protection of Cultural Property in the Event of Armed Conflict. Thirteenth Meeting UNESCO Headquarters, Paris 6-7 December 2017. Item 12 of the Provisional Agenda: Requests for the Granting of Enhanced Protection.

http://www.unesco.org/new/fileadmin/MULTIMEDIA/HQ/CLT/images/12COM_12_Enhanc ed_Protection_Requests_EN.pdf . 
UN Security Council. 2017. United Nations Security Council Resolution 2347.

https://www.undocs.org/S/RES/2347\%20(2017)

Vaughan-Thomas, Wynford. 1967. Madly in all Directions. London: Longmans.

Walasek, Helen. 2015. Bosnia and the Destruction of Cultural Heritage. London: Routledge.

Ward Perkins. 1944. Major J. B. W. Perkins [sic]. Art Collections Stored at CASTEL DEL MONTE (prov. BARI). 6 February 1944. NARA M1944, RG 237/0067.

[9456 words] 